\title{
convicted by the holy spirit: the rhetoric of fundamental Baptist conversion
}

\author{
SUSAN F. HARDING-University of Michigan
}

The Moral Majority and, more generally, the current political activism among fundamentalists are evidence of a deeper movement within American fundamentalism to abandon its historic separatism from "the world." Reverend Jerry Falwell and pastors allied with him are leading a faction of fundamentalists who are shifting the inner and outer boundaries that separate them from worldly culture.' They are breaking old taboos that constrained interactions with nonfundamentalists, claiming new cultural, political, and social territory, and refashioning themselves in church services, Sunday school, the family, in bed, on the air, in the political arena, in the news, in their literature, in Bible-study groups, classrooms, and daily interactions. In the process, they are transforming the fundamentalist mind and community, and altering what it means to be a fundamentalist.

It would seem a recipe for assimilation were it not for the fact that fundamentalists are primed-in a way, armed-for the confrontation. Their culture is premised on a commitment to assimilate "the world" on fundamentalist terms, and, indeed, fundamentalists routinely reproduce their cultural modes of interpretation through encountering, reconfiguring, and incorporating specimens of alien, worldly, culture. Most specifically, at the center of the language of fundamentalism is a bundle of strategies-symbolic, narrative, poetic, and rhetorical-for confronting individuals, singly and in groups, stripping them of their cultural assumptions, and investing them with a fundamentalist mode of organizing and interpreting experience.

This bundle of strategies is the rhetoric of conversion, and my purpose here is to scrutinize a sample of that rhetoric to decipher its sources of efficacy. In particular, how does the language and performance of fundamental Baptist witnessing convict and convert the unsaved listener? Witnessing, and conversion talk more generally (testifying, evangelizing, gospel preaching, spreading the Word), is rhetorical in the sense that it is an argument about the transformation of self that lost souls must undergo, and a method of bringing about that change in those who listen to it. Fundamental Baptist witnessing is not just a monologue that constitutes its speaker as a culturally specific person; it is also a dialogue that reconstitutes its listeners. My focus is on this latter aspect, on witnessing as the practice, the rite, of conversion.

To be converted, to be regenerated, to receive grace, to experience religion, to gain assurance, are so many phrases which denote the process, gradual or sudden, by which a self hitherto divided, and consciously wrong, inferior and unhappy, becomes unified and consciously right, superior and happy, in

Born-again Christian belief follows conversion, an inner transformation that quickens the supernatural imagination. Among fundamental Baptists, rhetoric, not ritual, is the primary vehicle of conversion. Witnesses "speak the gospel," the ramifying discourse and narrative of Christ. Listeners "come under conviction" as they appropriate the gospel in their inner speech. At "the moment of salvation," listeners become public speakers of the gospel. They "believe" in the sense of embracing a narrative tradition that rewords their experience in terms of a personal, triune God who intervenes in daily life and in history. [conversion, rhetoric, religion, evangelicalism, America] 
consequence of its firmer hold upon religious realities. This at least is what conversion signifies in general terms, whether or not we believe that direct divine operation is needed to bring such a moral change about [James 1906:160].

William James speculated that those who experienced dramatic conversions might have been born with a "melancholy disposition," a chronically "divided" mind, or else they had drunk "too deep of the cup of bitterness" (1906:158). Contemporary social scientists have also investigated "who" converts for some indication of "why" they convert. The notion is, apparently, that those who convert are somehow susceptible, vulnerable, in need, so the question is: "Why, what's wrong, what's unsettling them?" Or, "What's setting them up, how have they been predisposed to convert?" Social scientists scrutinize the external psychological and social conditions of converts looking for clues, patterns, and causes. They have found evidence in converts' lives of "psychological and social stress" (due to marriage problems, loss of a job, imprisonment, adolescence, dating, serious illness or accidents, encounters with death, "role" transitions, moving to a new city, going to college, and so on); "previous conditioning" (religious upbringing, education, class, gender); and "patterns of interpersonal influence" (by converted kin, friends, mentors). These correlations are not satisfying explanations, however, because, among other things, none of the circumstances have been found with enough regularity among converts, and the same circumstances have been found among nonconverts with too much regularity. ${ }^{2}$

There is also considerable literature, both popular and academic, on how various ritual practices and psychological techniques trigger experiences that result in a conversion from one worldview, or mind-set, to another. ${ }^{3}$ Distinct conversion methods (social seclusion, dramatic enactments, bodily markings, physical stress or pain, fasting, interrogation, chanting, silence, immobility, and so on) certainly pave the way for radical shifts in belief and commitment. What this approach, at least when plied by those who see conversion as a kind of brainwashing, tends to overlook is how persuasive in a quite unsensational way the recruiting rhetoric, the language of conversion as such, may be, how much it itself contributes to "dividing" the mind and bringing about conversion. The presumption that I think accounts for this oversight, and which in more muted form also guides many social scientific studies, is that "nobody in their right minds would believe this stuff." Since "belief" is irrational, some sort of suspension of normal thinking must have taken place and caused the convert to lose his or her grip on reality.

Social scientists through a variety of means generally do not let themselves get close enough to "belief" to understand it, or, for that matter, even to see what it is. Men and women convert to fundamental Christianity because they become convinced that supernatural reality is a fact, that Christ is the literal Son of God, that he did rise from the dead and is alive today, that the Holy Spirit is speaking to them, that Jesus will enter their hearts if they acknowledge their sins, that they will have eternal life, that God is really real. To continue to think otherwise would be irrational; it is disbelief that is false and unthinking. The appropriate question then is how does this supernatural order become real, known, experienced, absolutely irrefutable?

Among orthodox Protestants, and especially among fundamentalists, it is the Word, the gospel of Jesus Christ, written, spoken, heard, and read, that converts the unbeliever. The stresses, transitions, influences, conditioning, and techniques which social scientists scrutinize do not in themselves "explain," do not "cause," conversion to Christ. All they do is increase the likelihood that a person might listen to the gospel; they may "open" or "prepare a person's heart." It is the Word of God, the gospel, and, believers would add, the Holy Spirit, God himself, that converts, that "changes the heart." 4 We cannot understand fundamental Baptist conversion by looking only at what causes a person to listen to the gospel; the causes are innumerable. We must listen too, and we must explore the consequences of listening.

Witnessing and preaching are the two main situations in which believers "speak the gospel" most intensely. Preaching-the sermon-is a formal oration addressed to a body of believers and nonbelievers by an ordained or anointed speaker in church services and revivals. Sermons occur in the context of clear ritual format, of a collective, sanctifying scenario in which the 
mode of interpretation is enacted. Witnessing is more informal and often occurs in the course of what appears to be no more than a conversation between the witness, who is saved, and an unsaved listener. But it is no mere conversation. The witness and the unsaved "do not share a common understanding - either of the immediate situation or of reality more generally." Witnesses are "aware of this difference in understanding and self-consciously set out to change the views of those they address," and to create a "compelling religious reality completely at variance with their [listener's] experience" (Borker n.d.:1, 3).

Witnessing aims to separate novice listeners from their prior, given reality, to constitute a new, previously unperceived or indistinct, reality, and to impress that reality upon them; make it felt, heard, seen, known, undeniably real. The reality, or "truth," constituted in witnessing is, in part, a linguistic one: the supernatural is experienced as God's voice and his spirit is communicated and experienced through words. Much collective ritual among orthodox Protestants is likewise centered on words, on the Word. Especially among fundamentalists, church services and revivals are stripped of overt, imagistic, and sacramental material; relatively little happens visually, and spiritual realities are not communicated through sensuous, nonlinguistic means. In a way, witnessing is pure fundamentalist ritual, shorn of almost all distractions. It is the plainest, most concentrated method for revealing and transmitting the Word of God, one in which language is intensified, focused, and virtually shot at the unwashed listener.

Fundamentalists are by no means unique in their use of oratory to convert others. Their techniques and a good deal of the content of their conversion rhetoric are broadly shared among conservative charismatics and evangelicals. Indeed, the principle of conversion, of one person insinuating his or her mode of interpretation into the mind of another, informs all dialogue. ${ }^{5}$ What distinguishes fundamental Baptists from the rest of us is the degree to which they have formalized rhetorical techniques for converting alien others, the precise and distinctly unconscious manner in which those techniques appropriate the listener's dialogic imagination, and the particular transformations of self evoked in the listener.

preacher and gospel

Dusk had fallen by the time I left Covenant Baptist Church, but I was bothered by the light as I looked around the parking lot for my car. It seemed as if everything had moved slightly. The church was on the outskirts of one of the poorer parts of Lynchburg, and I would have to zigzag across a half-dozen big streets that bisect the city to get back to my motel. I knew I was in some kind of daze after my long talk with Reverend Cantrell; I usually am after an interview, and this one had been especially intense. Halfway across town, I pulled my car up to a stop sign, stopped, started into the intersection, and was very nearly smashed by a car that seemed to come upon me from nowhere very fast. I slammed on the brakes, sat stunned for a split second, and asked myself "What is God trying to tell me?"

It was my voice, but not my language. I had been invaded by the fundamental Baptist tongue I was investigating. As Reverend Cantrell would have put it, the Holy Spirit was "dealing with me," "speaking to my heart," "bringing me under conviction." He was showing me that "life is a passing thing," that death could take me in an instant, no matter how much control I fancied I had over my life, and that I should put my life in the Lord's hands before it was too late.

If we conceive of conversion as a process of acquiring a specific religious language, I was initiated into fundamental Baptist conversion as I sat in my car that evening in Lynchburg, awash in apprehension and relief. The process starts when an unregenerate listener begins to appropriate in his or her inner speech the regenerate speaker's language and its attendant view of the world. The speaker's language, now in the listener's voice, converts the listener's mind into a contested terrain, a divided self. At the moment of salvation, which may come quickly and easily, or much later after great inward turmoil, the listener becomes a speaker. The Christian tongue locks into some kind of central, controlling, dominant place; it has gone beyond 
the point of invading the listener's mind to occupy the listener's identity. The Holy Spirit, the very Word of God, has come, as fundamental Baptists say, to "indwell the heart of the believer," who may now publicly display in speech and action a personal, which is to say, conversational, relationship with God.

It was quite specifically Reverend Cantrell's language and mode of interpretation that unfurled itself in my mind as I contemplated my near accident. I had intended to interview him that afternoon, but within the first few minutes of our talk Reverend Cantrell assumed control of the dialogue and reframed my appointment to interview him into his opportunity to witness to me for an hour and a half.

A witnessing session minimally includes the gospel story (an exegesis of the death, burial, and resurrection of Jesus Christ), and a confrontation between the witness and his or her listener in which the witness invites or exhorts the listener to receive Christ as his or her personal Savior. Witnesses may also tell how they and others came to know the Lord as Savior; they may testify (give accounts of encounters between themselves and God, and other narrative evidence of God's intervention in the natural world) and deliver other doctrinal exegeses (regarding, for example, heaven and hell, the origin and nature of sin, or the ways of Satan).

Witnessing, like evangelistic preaching, "is intended to create a spiritual crisis by calling to the fore one's desperate and lost condition, which one may have been totally unaware of" (Hill 1985:26). This crisis is the onset of the conversion process, what fundamentalists call "coming under conviction," and is based on a direct experience of the divine. You know when the Holy Spirit convicts you of, or "makes you see," your sins. Conviction effects a deep sensation of one's own impurity and separation from God, or one's "sinfulness," one's "sin nature," and a sense that "something has to be done about it." We shall see that the inner speech of "convicted sinners" is transformed as they are alienated from their previous voices ("the old self," "natural man"); cast into a limbo ("lost," "in need," "searching"), that is to say, somehow in a liminal state, a state of confusion and speechlessness; and begin to hear a new voice ("an inaudible voice," "the Holy Spirit").

It is a kind of inner rite of passage that is completed when sinners are "saved," or "bornagain," "regenerated," "washed in the blood of Christ." Salvation is experienced as a release from the bondage of sin and a personal reconciliation with God. "A new self, "spiritual man," emerges and the supernatural imagination is cut loose as the newborn Christian "accepts the meaning of the gospel" and begins to speak the language of Christ. For many, as it was for Benetta Jules-Rosette (1976:135), who studied among, and joined, the Apostles of John Maranke in Africa, conversion is "a powerful clash resulting from the shift from one realm of thought and action to another, a moment of specific shock. Under this shock, the very terms of physical existence seem to alter."

The power of Reverend Cantrell's rhetoric to induce liminality was seconded in my case by several circumstances - I was on a number of margins. It was late afternoon, and his church was on the edge of town. We were in a corner of the church, in his study, alone, on the edge of propriety. I was beginning my fieldwork. And Reverend Cantrell seemed to me a peripheral character in my study. Having grown up with Jerry Falwell and trained to be a preacher at his Liberty Bible Institute, he was in but not quite of Falwell's empire. His congregation appeared to consist largely of white working class or unemployed men and women and their children. Covenant Baptist Church was, in his words, "a solid work," with about 350 members, and it sustained a number of outreaches, but Reverend Cantrell and his congregation were not engaged in any of the political or cultural activism that has earned Jerry Falwell a national reputation in the last few years.

Reverend Cantrell is a tall, trim, and muscular man, his silvery gray hair piled up from his forehead in waves an inch or two high. He sat at his desk, I to its side, and he looked me in the eye the entire time we talked. Later I realized that most people who sat in the chair I was sitting in came to Reverend Cantrell for spiritual help. 
Born-again believers say that unbelievers cannot understand their faith. Jeanne Favret-Saada (1980:22) came to a similar conclusion while studying witchcraft in the Bocage region of France. "For anyone who wants to understand the meaning of [witchcraft] discourse, there is no other solution but to practice it oneself, to become one's informant." This is so, she tells us, because there are only two "positions" from which a person speaks or hears witchcraft talk, bewitched and unwitcher; if you are neither, you will never even hear others speaking the discourse (Favret-Saada 1980:16). The situation is, of course, quite different among fundamentalists. Gospel talk is public and targets outsiders, nonbelievers; but, as in witchcraft, there is no such thing as a neutral, "participant-observer" position, no place for an ethnographer who seeks "information." Either you are lost, or you are saved.

When I went to Lynchburg, I was naive enough to think I could be detached, that I could participate in the culture I was observing without partaking of it. I could come and stay for months, talk mainly to church people, attempt to "learn the language," ask questions based on respect and knowledge; and still remain outside, separate, obscure about what I believed and disbelieved. But there was no such ground. I might think there was, but they did not, no matter what I said. It was inconceivable to them that anyone with an appetite for the gospel as great as mine was simply "gathering information," was just there "to write a book." No, I was "searching." "God works in mysterious ways." In my case, he seemed to be letting me find my way to him through this book I said I was writing about them. Several people told me as much; others just seemed amused when I told them what I was doing and gave me a look that indicated they knew better. My story about what I was doing there, instead of protecting me from going native (a kind of ethnographer's verbal fetish), located me in their world: I was a lost soul on the brink of salvation. And Reverend Cantrell spoke to me accordingly.

I asked him first how he became a pastor, and he took 15 minutes to answer me. I had expected to get something akin to "information" or "facts," and he gave me a long story of personal transformation, one that began with how he had been saved and had served the Lord before he was called to preach. He never acknowledged my academic project and seemed to speak to me as if I were what they call a "nominal Christian," someone who might think she was a Christian but who had never been saved. He could assume I was not born-again simply because I did not indicate I was, as believers do when they meet, if only by a turn of phrase. Certainly, he was aware of himself as witnessing to me, and he had been trained, formally and informally, in "soul-winning techniques," but his manner and his method seemed to draw more on unconscious intuition than deliberate design.

There are at least five distinct rhetorical movements in Reverend Cantrell's witnessing talk: equating his present listener with the listeners in his stories; defining the listener as lost; defining the speaker as saved; transforming his narrative listeners into speakers; exhorting his present listener to speak. I will trace these movements by exhibiting and expanding on sequential pieces of Cantrell's speech, hoping to show you, as much as tell you, what conversion and belief are among fundamental Baptists.

In this, his conversion narrative, Reverend Cantrell defined being "lost" and being "saved" and how he moved from one position to the other. Lostness, he indicated, is a position from which you listen, and salvation is one from which you speak. Note, too, how Cantrell began to pull me in and placed me into his narrative in the position of listener. Unfortunately, in words flattened out on a page, we may hear only suggestions of his southern, fundamental Baptist, accent, his peculiar cadence, intonation, pausing, pitch, and stress.

I was saved when I was 15 years old. I was a member of a Methodist church all of my life as a child. At the age of 15 I still had not heard the gospel story of Jesus Christ and how that he died for our sins. I was instructed as a child coming up in the Methodist movement just to live a good life, to be morally good and to maintain all of those particular statuses, and I would be okay. Now I was invited by a friend to visit a Baptist church. ... And this was an independent fundamental Baptist church. And of course they had one of those hell-fire-and-damnation preachers in there, and he got down on my case that night. And I began to look at things and I realized there was something missing in my life. Because, though we've never seen God, we're still aware of the fact that he is present, we know he's there. And even though I wasn't saved I knew there was something bombarding my life that was beyond my power to 
see or to really understand at the time. And I couldn't understand why I wasn't receiving what I needed in the Methodist church. So after attending about three of their services-and incidentally they were in revival that week - then the spirit of God began to convict me about my place in life and how that I was lost and had not yet turned my whole life over to Christ, so I was saved that week, I went forward and gave my heart to Christ. Now this is a process that some folks misconstrue along the highways of life. They think, you know, perhaps that because I joined the church, and I'm a good member, faithful, I tithe, I put all the nine yards in that really belongs there . . ., they think often that this is all that's necessary. But $I$ realized that night there was a need in my life and that need was met, and so much the spirit of God came to live in my heart. Now this is God's gift to every person that receives Christ. So I joined that particular church after about a month of visiting there. But I was first saved and then I followed Christ to baptism, which I hadn't been baptized before. Of course the Methodist Church, they sprinkle, and I don't have any argument with them there, other than the fact that I believe the Bible teaches immersion. And then after this, my life began to grow and materialize into something that was real, something that I could really identify with. That emptiness that was there before was now being replaced by something that had meaning and purpose in it. And 1 began to sense the need of telling others about what had happened to me. And basically I think perhaps the change could be detected in my life, as the Bible declares, that when a person is saved, the old man, the old person, or the character that they were passes away, and then they become a new creation in Christ lesus. That is to say, they might be a character that may be drinking and cutting up and carrying on and a variety of other things that are ill toward God. All of these things began to dissolve away. I found that I had no desires for these things, but then I began to abhor them. I actually began to hate them. And this was in accordance with the Scriptures as I found out later. And then as my life began to mature in Christ I found that I too could win others to Christ the same way I was won: by simply telling them that there's a heaven to gain and a hell to shun.

\section{enlisting the listener}

Numerous poetic and performance features teem on the surface of Reverend Cantrell's speech. There are verse markers ("and" and "now"), special codes, figurative language, symbolic and metaphoric parallelism, and appeals to tradition. These features, according to Richard Bauman (1977:15-24), mark the text as an oral performance and indicate a special relationship between performer and listener, one in which the performer assumes responsibility for display of competence, indirectly instructs the listener about how to interpret messages, and invites, elicits, participation, binding the listener to the performer in a relationship of dependence and keeping the listener caught up in the display.

Reverend Cantrell also communicated my relationship to his speech more directly through his use of pronouns (emphasis added): " 1 still had not heard the gospel story of Jesus Christ and how that he died for our sins." "Because, though we've never seen God, we're still aware of the fact that he is present, we know he's there." Cantrell continued to place me in his narrative during the rest of the time we talked by using the "royal we," and he frequently shifted his pronouns and at times used "you" ambiguously, as a personal and impersonal pronoun. His listener by these means became the subject of a whole range of presuppositions posited in such a way that they were difficult to resist.

Reverend Cantrell at one point in this initial speech and at several points later on quite overtly identified me with his narrative listeners. The central, reiterated narrative structure in his witnessing was a dialogic encounter between person and God, or between a lost listener and a saved speaker. The context of his witnessing of course was also dialogic: Reverend Cantrell and I were engaged in a dialogue, one in which he, who was saved, was speaking, and I, who was not saved, was listening. Early in his conversion narrative, Reverend Cantrell began to collapse these parallel levels of dialogic structure and thereby place me in his stories, in his speech: "Now I was invited by a friend to visit a Baptist church . . . and of course this was an independent fundamental Baptist church. And of course they had one of those hell-fire-anddamnation preachers in there, and he got down on my case that night." In describing his context the night he was converted, Cantrell called attention to our, his and my, context. He too was a hell-fire-and-damnation preacher, and 1 , in effect, was informed that he would be getting down on my case and that I might be converted that afternoon. This is no mere innuendo: Cantrell was thus aligning me and my encounter with him with the listening persons and their encounters with God in his stories. Whenever a spiritualized speaker addressed a wayward 
listener, the speaker would also be addressing me. I too would be transfigured, if only by degrees, by the very act of listening to Milton Cantrell.

Reverend Cantrell reminded me of my position in his narrative several times. I heard it faintly when he said, "I found that I too could win others to Christ the same way I was won: by simply telling them that there's a heaven to gain and a hell to shun." He was more explicit later, when he told me how he was called to preach.

Now when I had my calling at age 29, I was operating a service station. And I was in the station one afternoon, working on a car. And God did not speak to me with an audible voice, but he spoke to my heart. And there was a conversation going on much like the one that's here. I' $m$ doing the talking and you're listening. And God was doing the talking and I was listening. I was down under the car, changing the oil, and ... God was just dealing with me about doing this. And I said, "I can't do that." And much like Moses when the Word called him to do something, he said, "I can't even talk." And God said, "Well, I'll send your brother Aaron to help you." So every excuse I would come up with, he would head me off by instructing me that he would do something to meet my shortcomings. So I finally surrendered in the sense of the word that afternoon.

If I had any doubt about where I belonged in Reverend Cantrell's talk, this passage dispelled it. God spoke to him under his car that afternoon just as Cantrell was speaking to me in his office. I am the listener; he is the speaker; that which transpires in his narrative dialogues shall somehow transpire between us. Reverend Cantrell also introduced, and located me within, another parallel level of dialogic structure, between God and Biblical figures, in this passage. I must listen to Cantrell as long ago Moses, and much later Cantrell, listened to God. Clues such as these inform, or, rather, persuade, the listener that the witness's words, though they appear to be about the witness and about other characters on the narrative surface, are on a deep level about the listener: You, too, are a character in these stories; these stories are about you.

\section{lostness}

Keeping in mind that much of what Reverend Cantrell said about himself as he came under conviction also applied to his listener, let us examine how he fashioned the lost soul, the sinner, the person in need of salvation.

Young Cantrell realized there was something missing in his life. He needed something he wasn't getting; he was lost. He was carrying on in a variety of ways that were ill toward Cod. His life was empty and lacked meaning and purpose; it was not maturing or growing into something real. Yet he knew there was something bombarding his life beyond his power to see or really understand; though he had never seen God, he was still aware of his presence, he knew he was there. Cantrell was ostensibly describing himself here, but because he had put me in his narrative in his place, he was also describing me; indeed, he was refashioning me.

I am emptied, stripped of all vestiges of personality and uniqueness. My life is rendered meaningless, my past erased. I am primarily distinguished by what I lack, and, given my lacking, by what I need. I stand for absence, for void, yet I am aware of something more, something missing, unseen, hidden, and I come to need that, to desire it, perhaps to crave it, and am thus launched on a quest for affirmation and revelation which may be achieved only through conversion. All this is accomplished in me by implication and presupposition, not by direct argument. My consent is not sought; I am implicated, already enlisted as a collaborator, in my own metamorphosis.

\section{instilling the spirit}

As well as constituting the listener as a lost soul, Reverend Cantrell in his conversion story began to fashion the speaker, the saved soul, as he narratively moved himself, you could say, converted himself, from lost listener to a saved speaker of the Word of God.

The hell-fire-and-damnation speaker getting down on Cantrell's case shortly became the spirit of God convicting him about his place in life--that he was lost and had not yet given his 
whole life over to Christ. He was saved, and he went forward and gave his heart to Christ, and the spirit of God came to live in his heart. His life began to grow and materialize into something that was real, something that had meaning and purpose in it. His old character and its desires passed away. Then he began to sense the need of telling others about what had happened to him and found that he too could win others to Christ in the same way that he was won. The spirit of God first "worked on" Cantrell, then entered and transformed him, and finally spoke through him to bring others under conviction.

God's spirit, the Holy Spirit converts sinners, but he (the fundamental Baptist Holy Spirit is a male person) speaks through those who preach the gospel. Preachers speak the Word of God; God speaks through them. Reverend Cantrell started a church in a storefront after God called him, and on the first day of services, he wondered why anyone would come there to hear him preach. Later he realized "it was the Word of God they must come to hear, and not me. It's the Word of God that must cause the change." The change is caused not by God as an external agent, but by the Word, the spirit, of God, which is internalized when a person accepts Christ. "By nature, Adam and Eve, you know, they caused the problem, but they invested into every one of us that would be borned a similar nature. Now this nature can be wiped clean, it can be changed by once again instilling the spirit of God within us." Here, according to Reverend Cantrell, is how the Holy Spirit works his magic.

Now I realize many times when I preach, the Bible says preaching is as of foolishness. But there is another agent working while I'm preaching. And he's the Holy Spirit. And he's the one that grips the heart. I could throw a rock at you and you could throw another one at me. But if I make a statement from the Word of God, and the Holy Spirit bears me up, and he begins to deal with your heart about it, then when we have parted company, he's still working, and I'm gone. Now until we're saved, he lives without us, but when we're saved, he comes to live within us, and this is what we mean by receiving the Lord into us. When he comes to live in us he comes in the form of the Holy Spirit. I've never seen him. But like a mother with a child, she's not seen her unborn baby, but she knows he's there. You say, "How does she know?" She feels life and movement within her. Now the spirit of God is like another voice, like another party. And he is not a figment of the imagination. But the Bible says, he's a real personality, a real person. And actually he can catch your next word and stop it, if you're sensitive to him. And if you're not, you put a piece of tape across his mouth, you can fold him back into the innermost rooms of your heart and give him no liberty. But if you let him, he becomes the tutor of your life, the instructor, the guide, the teacher. And he tells-now when I use the term "tells," he speaks to my heart and he gives me-you've seen the time when you would sense something and you couldn't really say another person was talking to you, but you sense you ought to do something. You were impressed to get up and go see somebody or something. All right, this is the way the Holy Spirit works with me. He impresses me. He moves upon my heart to do certain things. And sometimes he gives me spiritual discernment that's almost like reading another person's mind. Many times l've had people sit down to talk with me, and the Holy Spirit would almost link my mind up with theirs and tell me certain things. And I cannot explain it, but this is because he is a third part of the Godhead. In reality, it's God living within us. Now once he's in here, the things that I used to love to do-and I mean I had a real passion for some things before I got saved - and when he came to live within me, all of a sudden I found that I hated and despised those things. Well, it wasn't my flesh, it was Christ living within me that was despising those things because they were anti- and alien to his nature.

Fundamental Baptists, especially preachers, are acutely aware of the power of witnessing and of the gospel, of the rhetoric of conversion in general. They attribute its transforming power to the workings of the Holy Spirit, that is, to supernatural agencies, but their glosses on those agencies invariably refer to words, to speaking and hearing and reading. In effect, in a coded way, they recognize language as a medium, even a subject, of religious experience, and they coach the unconverted in the linguistic dimension of conversion.

The Holy Spirit uses Reverend Cantrell's speech, as it were, to remodel his listeners' inner speech. The Holy Spirit impresses on Cantrell what to say and deals with the hearts of his listeners, bearing him up, after he's gone. "The heart" is contrasted with "the head," and seems to mark the difference between unconscious and conscious knowledge and belief. The Holy Spirit, the Word, "works on" the unconscious mind to bring the conscious mind "under conviction." As listeners appropriate the gospel, the Holy Spirit penetrates the conscious mind and becomes "another voice," "a real person," who begins to recast their inner speech. After sal- 
vation, the voice of the Holy Spirit "guides" converts, gives them "discernment," and seems to alter the very chemistry of desire.

second birth

Reverend Cantrell spelled out the moment of salvation elliptically in his own conversion narrative, and he elaborated it in his disquisition on Holy Spirit. He also posited the moment of salvation in highly charged symbolic terms, in Biblical exegeses on birth and death, flesh, spirit, blood, and sacrifice.

Cantrell drew on well-established parallels in evangelical culture between the narratives of Christ's death (the gospel story) and of personal conversion, between the cosmic order spelled out in the Bible from the Garden of Eden to Calvary and the epic of each individual in the face of inevitable death. The gospel story defines the movement, the passage that all believers must endure, from suffering and dying (coming under conviction), to burial (silence, absence, void), and resurrection (converting, being reborn). As God restored man to himself by sacrificing his son on the cross, so the unsaved may restore themselves to God by "dying" to their old selves and being born anew in Christ. All they need do is acknowledge their "sin nature," accept that Christ died for their sins, and ask him into their hearts. It is these words, once genuinely spoken, that resurrect a dead soul, that instill in the newborn believer the Holy Spirit, the very voice of God.

Reverend Cantrell began to elaborate the connection between the gospel story and salvation, as witnesses often do, by talking about Nicodemus, who came to visit Jesus one night and said to him, as Cantrell put it, "Now you've got something that we've missed."

Jesus said, "Nicodemus, l'm going to limit my words in talking to you. Listen carefully." He said, "Ye must be borned again. Ye must be borned again." And Nicodemus said, "How in the world can a man be born when he's old? Is it possible that I could enter again a second time into my mother's womb and be born?" Jesus said "No, you didn't listen. I'm going to repeat one more time. . . Y You must be borned again. . . That which is born of flesh is flesh. That which is born of spirit is spirit. Marvel not that I say, you've already had one birth, but you need more. You need the birth that's going to change you from the one you received from Adam, which is a sinful nature. You've already experienced that first birth and you're full of yourself. But now you need the second birth, the one that will give you this indwelling of the spirit of God." Now when I was born, I was born physically of my mother. Jesus said, "You must be borned of the water first, of the spirit second." When a child is about to be born, it's first enclosed in the mother's womb. Is that true? [Yes.] That water must be broke before the child can be born. Now this is a representation of the first birth. He said, "You must be born of the water first, Nicodemus, you've already been born, you're here." But then he said, "Now you must be born by the spirit." Your mother birthed you the first time. And your mother cannot give you this spiritual birth. So this must come from above. Now God gives this second birth. IHow does the second birth change a person?] Okay, Susan, you have the characteristics and the traits of your mother and your father. True? [Yes.] All right. Now the second birth will give you the characteristics or the traits of the Father that birthed you. Now the first time when you were born, you couldn't help your mother. If your life had depended on it, you had to depend upon her strength to bring you into this world. True? [Yes.] Now when we're saved, or borned again, this is absolutely and totally dependent upon God. Now where did the birth take place at? It had to be a birth of such a caliber that it had to take care of the whole world. And this was a place called Calvary. Jesus, when he was dying, was shedding his blood, and the Old Testament says that without the shedding of blood there is no remission, there can be no forgiveness for sin. So blood-the innocent-and God typified this in the animal sacrifices of the Old Testament. When Adam and Eve sinned, Genesis 3:21 said he slew innocent animals. And he took the skin off these animals, and he covered their nakedness, which is the type of giving them a covering which is representative of righteousness, and the blood was used to atone for their sins. ... Atonement means to cover and the blood of the animals of the Old Testament typified one day that Christ would come, shed his blood, but then this blood, this blood being shed now, brings about redemption and not atonement which is a temporal covering. For thousands of years, the Jews under the Mosaic economy offered up sacrifice of animalsyou've probably read that-and they did this because this was representative of one day a coming Savior. You remember the incident in Exodus, about Abraham went to offer his son Isaac on Mt. Moriah. And the Bible says that Isaac the son said, "Father" - he didn't know what was going on-he said, "Here's the altar, here's the wood, here's the knife, here's the fire, but where's the sacrifice? Where's the lamb?" And Abraham said, "My son, God himself shall provide a sacrifice. A lamb." Now we go down several thousand years into the future, and John the Baptist, when he saw Jesus Christ for the first time, he toid the disciples that were with him, he said, "Behold, take a look, here is the lamb of God that will take 
away the sins of the world." And the lamb of God was Jesus Christ. Of course, Isaac was not slain. There was a ram caught in the thicket which was a type of substitution. So Jesus Christ died in my place as a substitution for me. .. . Now God so loved me that God himself died for me because Jesus Christ is a Very God.

"The conquest of death is the ultimate goal of Christianity" (Graham 1983:203), and victory is achieved when sinners are "borned again" and the spirit of God is instilled in them. Rebirth is totally dependent upon the grace of God, as a baby is totally dependent on its mother for its birth. Symbolically, Reverend Cantrell first moved his listener from the first birth, the mother, flesh, and water breaking, to the second birth, the Father, spirit, and blood shed. The second (spirit/male) birth takes over, subverts and cancels out the consequences of, the first (flesh/female), releasing the sinner from the wages of sin, death. The womb of the second birth was the cross at Calvary; Christ mediated between the first (flesh/female) and second (spirit/male) birth and created the possibility of reconciliation with God.

After spelling out the contrast between the first and the second birth, Reverend Cantrell moved deeper into a discussion of blood, of "the innocent." The blood of animals sacrificed under the law of Moses was a temporal, or a temporary and earthly, covering (atonement). The blood of Christ provided eternal, heavenly, remission from sin (redemption). Through animal sacrifice, humans asked God's forgiveness and might stay his judgment, but they were still condemned to die. Only the self-sacrifice of God himself could lift the curse of Adam and Eve and overturn the Mosaic economy. God gave to man that which he had not asked Abraham to give, his own son, his own flesh and blood, and so made available eternal life to those who would believe. God no longer asks the blood of animals from men and women. He asks for repentance and faith in the saving grace of Christ. A sacrifice is still due, namely, the flesh-bound self of the first birth, which is offered up in the act of believing.

Animal blood is linked to spiritual death; it can only "cover" $\sin$ (separation from God, death) and nakedness (meaninglessness, void); and it only represents, or typifies, righteousness (order, reunion with God) and a coming Savior. Christ's blood actually saves men and women from spiritual death; Christ's death "substitutes" for them and creates eternal life. Here Cantrell was using the New Testament to overtake, subvert, and transform the Old Testament; he seemed to suggest that Mosaic sacrifice only approximated, or signaled to, God, while born-again sacrifice relates directly to God, and, in a way, becomes God.

On a symbolic level, Cantrell argued that it was Christ's blood that made this transition possible. But narratively-looking at the form his argument took on the surface of his whole juxtaposition of tales, from Nicodemus to Abraham and Isaac to Christ on the cross-Cantrell emphasized the importance of spoken language, of dialogue, in making the passage from one world to the next. He repeatedly relied on dialogue (between Jesus and Nicodemus, himself and me, Isaac and Abraham, John the Baptist and the disciples) to set up the dilemma of human choice. In this respect, he was speaking as much within Old as New Testament tradition. Robert Alter points out that Old Testament writers used "narration-through-dialogue" to highlight

human will confronted with alternatives which it may choose on its own or submit to divine intervention. Articulated language provides the indispensible model for defining [the] rhythm of political or historical alternatives, question and response, creaturely uncertainty over against the Creator's intermittently revealed design, because in the biblical view of reality words underlie reality [Alter 1981:69].

And it is through spoken dialogue, through witnessing, that each sinner is confronted with and makes the choice to accept or reject Christ.

\section{do you know Christ?}

Reverend Cantrell concluded an hour of virtually uninterrupted talk with a veritable gospel poem that fully realized the complex, holistic meaning of blood as birth and as death and emphasized the mutuality of the sacrifice and reconciliation between humans and God. Cantrell's speech is strikingly Biblical here, an elaboration of several verses from the Old Testament Book of Ezekiel, 6 though again he converts it to New Testament ends. 
My birth, it belongs to God. God made me. And then Paul said, "When I've been saved, I've been bought with a price." What was that price? His life at Calvary. That's what he gave for me. He ransomed me out of the, you might say, the slave markets of sin and brought me into a right relationship. And when I was unworthy, the Bible said he loved me. When I was wretched and naked, when I was borned, the prophets said it was like I was thrown out onto the ground. I had not been washed in salt. I had not been suppled [washed in water]. I had not been bathed in olive oil. I was laying there in my own blood, dying. And when he saw me, there was nothing about me that really made me desirable. Yet he looked beyond all of my faults and saw my needs, and he come, and he loved me, and he died for me. And he even made it available so that I could know this, and when I come to that knowledge, I had no alternative but to want to run to the one that loved me. Because nobody had ever cared for me like Jesus. And that's about the size of the story. Nobody.

Reverend Cantrell then turned to me and asked, "Now Susan, let me ask you a question. Do you know Christ as your personal Savior?" He asked me several more questions. "Do you believe in God?" "What if you died today?" Then he told me a story of a man he buried a few weeks before who had choked to death on some food. "Had no idea he would be sent out into eternity." "Life is just an uncertain thing." He inquired again into my faith. "Have you ever sensed the presence of God?" Then he told me about a man who, at 40 , lamented that he'd been "looking for a wife for so long." Cantrell told him "I think God has sent you the right woman, probably 20 times, and you turned her down." He said the man had overlooked the orchid and all the other beautiful flowers while looking for a rose. "Can you identify with that?"

Then Reverend Cantrell brought his exhortation to a rather stunning conclusion.

Now if in this life, the Bible says, only we have hope, then we of all men are most miserable. But you see my life, my hope, is in the life to come, and I realize this life is a passing thing. Jeremiah says it's like a vapor. It appears but for a little while, and then vanishes. We know how uncertain life is. We're just not sure how long things are going to go. I went to work one morning. I had some work to do on a Saturday morning. And one of my sons was 14 years old. And the other one was 15 years old. And we got up that morning. And I went in, and I rassled with my son and rassled him out of bed, the one that was 14. And we got up that morning and ate breakfast. We opened the Word of God. We read and we prayed together as a family, my wife, my two sons, and I. And I went on to do that work that morning. It was a Saturday. And I had something I wanted to move. And I was operating a crane. And I accidently killed him that morning. And I looked at God, and I said "Lord, you told me in your Word that all things work together for good to those that love you, especially those that are called according to your purpose." And I said, "I've served you faithfully. And I've loved you. And I've given you my heart, my life, my soul, given you everything about me. And now I can't understand this, why you've taken my son." And God didn't speak with a voice that I heard with my ear but he spoke to my heart. He said, "Milton, you know maybe you don't understand what I've done at this particular time, but, can you accept it?" And I said, "Yes sir, I can accept it." And, Susan, when I made that statement, and I settled that in my own heart, and I said "Lord, I accept it though I don't understand it," I don't know where to say it came from other than that God gave it to me, but he gave me a peace in my soul. And I have not questioned it since. Now I went and shared it with my wife. I said, "Shirley," I said, "God said all things would work together for the good to us because we loved him." And she said basically the same thing I did, "Well, I don't understand. This isn't good." But I said, "Yeah, but God said it is good." And I shared with her, and when I shared this with her, she came of the same opinion. And we watched them close the casket on that little fellow and my, he was just super. I mean, he was almost my hearthrob, you know, that was my baby. And yet he died in my arms. And yet I looked at God and I said, "Lord, I'm going to love you if you take my other son. I'm going to love you if you take my wife. I'm going to love you if you take my health, if you strip me of everything I've got, I'm going to love you." Now I'm saying that because, Susan, he is real. This is not mythology. I'm 46 years old, and I'm no fool. God is alive. And his son lives in my heart. And I'd love for him to live in your heart. Of all that I could give or think of ever giving over to you, I hope that what we've talked about here today will help you make that decision, to let him come into your heart, and then he will be your tutor. And he'll instruct you in things that perhaps l've stumbled over today. Sometimes the vocabulary may not be appropriate to really describe the depth and the detail the things that need to be said. But this is where the Holy Spirit can make intercession for us. The Bible says with groanings and utterings that we just cannot utter. I may miss something, but he'll bring it out. I may present something, and you don't understand it. But he will reveal it to you. This is what the whole thing is about.

Reverend Cantrell began his ultimate narrative on a note of wistful resignation. Life is a passing thing, a vapor; it's here for a little while and then vanishes. Without pause, he shifted into a homey story about getting his sons up one Saturday morning, opening and reading the Word of God, and going out to work in the yard. Then he delivered a split-second narrative shock: "And I accidently killed him that morning." The sentence disrupts, it stabs, but before it is absorbed Cantrell shifted to the real point-his conversation with God. God asked Milton to 
accept what he, God, had not asked Abraham to accept and what he, God himself, was willing to give: his son's death. And Milton obeyed: "Yes, sir. I can accept it." This sentence, in a moment as extreme and extraordinary as the tragic death of his son by his own hand, is what God asked of him to restore order in himself and in the world. By speaking his obedience, his submission to God's will, they were reconciled, and Cantrell received in return peace in his soul, an eager willingness to give still more. The same gifts, he concluded, awaited me, if only I too would accept Christ. "This is what the whole thing is about."

\section{conclusion}

If conversion is a process of acquiring a specific religious language, and witnessing is an orthodox Protestant rite of conversion, then, if you are willing to be witnessed to, if you are seriously willing to listen to the gospel, you have begun to convert. Listening to the gospel initiates the unwashed into the Word, the language of God.

The single most important unconscious clue I gave Reverend Cantrell that I was "susceptible" to conversion was that I was willing to listen to the gospel. Crises, transitions, and upbringing as such do not lead you to convert; they may make you more likely to listen, and anything that makes you more likely to listen, including the work of ethnography, is actually what makes you susceptible.

"Susceptible" implies passivity, but I was not passively listening to Reverend Cantrell. I was struggling mightily against the grain of my ignorance and incredulity to make sense of what he was saying. His language was so intense and strange, yet deceptively plain and familiar, full of complex nuances and pushes and pulls, that I had no time, no spare inner speech, to "interpret" him, to rework what he said into my own words, as he talked. I just gripped my chair, as it were, and took it in straight. I was willfully uncritical as well, in the sense that I wanted to understand, as best I could, his words from his point of view, to assume his position, to make his speech mine. ${ }^{7}$ It was not exactly what Reverend Cantrell said that brought me under conviction; it is that I took it up, merely by listening to him actively and uncritically. ${ }^{8}$

The membrane between disbelief and belief is much thinner than we think. All I had to do was to listen to my witness and to struggle to understand him. Just doing so did not make me a fundamental Baptist born-again believer, but it drew me across that membrane in tiny ways so that I began to acquire the knowledge and vision and sensibilities, to share the experience, of a believer.

Believers and disbelievers assert there is no middle ground: You are either one or the other. You cannot both believe and disbelieve. But that is precisely what it means to be under conviction. You do not believe in the sense of public declarations, but you gradually come to respond to, and interpret, and act in the world as if you were a believer. It is a state of unconscious belief, experienced with more or less turmoil and anxiety, depending on how strong your disbelieving voices are. It also depends for the ethnographer on how adamant your colleagues are about the "dangers" of doing "this kind of fieldwork." I was given to think my credibility depended on my resisting any experience of born-again belief. The irony is that this space between belief and disbelief, or rather the paradoxical space of overlap, is also the space of ethnography. We must enter it to do our work. ${ }^{9}$

Reverend Cantrell's testimony was a hodgepodge of stories sewn together with "the scarlet thread of redemption," not a series of "logical" or "empirical" arguments. He persuaded me narratively. Disbelief is a conscious refusal to accept a particular version of reality, and believing involves the conscious acceptance of "doctrines," of particular claims about reality and one's relationship to it. But disbelief is also, in the case of evangelical Christianity at least, an unconscious refusal to participate in a particular narrative mode of knowing reality. Likewise, belief also involves an unconscious willingness to join a narrative tradition, a way of knowing and being through storytelling, through giving and taking stories. You cannot give born-again 
stories, you cannot fashion them, without acknowledging belief, but you can take them, you can absorb them, and that's how you "believe" when you are under conviction. You get caught up in the stories, no matter what your conscious beliefs and disbeliefs are.

I was caught up in Reverend Cantrell's stories_-I had "caught" his language-enough to "hear God" when I almost collided with another car that afternoon. Indeed, the near accident did not seem like an accident at all, for there is no such thing as a coincidence in born-again culture; God's hand is everywhere. Gospel talk casts in your subliminal mind, your "heart," a Biblical rhythm of alternatives, a vibrating template, ready to fire God's speech given a context in which you seem to have a choice to submit to God's will or ply your own. Preachers construct such contexts verbally, and life presents them virtually every day-those apertures in the ordinary, when the seams split and you encounter the unknown, the unexpected, the uncontrollable, the irrational, the uncanny, the miraculous. These are moments ripe for supernatural harvesting, moments when fear or awe mutes your natural voices and God may speak, offering you the opportunity to speak back.

Coming under conviction (listening to gospel stories or voices) is easy compared to getting saved (speaking; telling stories). When you come under conviction, you cross through a membrane into belief; when you get saved, you cross another membrane out of disbelief. This passage is more problematic for some lost souls, for what outsiders would say were reasons of education, class, intellect, and insiders would say was hardness of the heart, ego or pride, the work of the devil. However you explain it, getting saved among fundamental Baptists involves giving up disbelief (not just suspending it, but disavowing it), accepting born-again belief (your conversational relationship to God) as the centering principle of your identity, your personal and public life, your view of human nature and history, and joining a particular narrative tradition to which you willingly submit your past, present, and future as a speaker.

One more reason Reverend Cantrell was a compelling witness was the extent to which, and eloquence with which, he gave his life to the language of Christ. This willingness to "submit one's life to God," to narrate one's experience and fashion stories out of it in dialogue with God's will and Biblical truths, makes God, and his Word, most real and known and irrefutable, to oneself and to one's listener. Reverend Cantrell understood this, at least intuitively, well enough to tell me about killing his son just before his final pitch for my soul. The story disarmed me not only because he had killed his own son and because he so crisply gave up his grief and his guilt to God, but because he was telling me, a stranger, about it. He "sacrificed his own son" to his narrative tradition with a calm and assurance, a peace of heart, that I still find difficult to accept. Often that afternoon I found myself at a loss for words as Cantrell narratively generated what for me were novel grounds for knowing and for speaking, but the story of his son's death struck me dumb. He might as well have gone up in a puff of smoke.

A cynic, second-guessing Reverend Cantrell's motives, would say he was manipulative, that he used this painful story to "get to" his listener. But from within born-again culture, this telling was the ultimate evidence of belief, Cantrell's moment of maximum authenticity. If he told me the story for effect, it was to effect the reality of God in me. What God said to him and he said to God in that tragic moment meant that God is absolutely real. This was his own conclusion: "Now I'm saying that, Susan, because he is real. This is not mythology. I'm 46 years old, and I'm no fool. God is alive. And his Son lives in my heart."

Among fundamentalist Baptists, the Holy Spirit brings you under conviction by speaking to your heart. Once you are saved, the Holy Spirit assumes your voice, speaks through you, and begins to reword your life. Listening to the gospel enables you to experience belief, as it were, vicariously. But generative belief, belief that indisputably transfigures you and your reality, belief that becomes you, comes only through speech. Among fundamental Baptists, speaking is believing. 


\section{notes}

Acknowledgments. Many thanks to Faye Ginsburg, Frances FitzGerald, Shirley Lindenbaum, Bruce Mannheim, Roy Rappaport, Rayna Rapp, Jane Schneider, Cynthia Sowers, Kathleen Stewart, Harriet Whitehead, Robert Wuthnow, and Marilyn Young for their comments and encouragement.

'All evangelical Christians have received Jesus Christ as their personal Savior and are "born-again." In 1982, Gallup (p. 31) estimated over 50 million adult Americans made this claim. Among them, those who call themselves fundamentalists are the most doctrinally strict, dispensationalist (their eschatology "raptures" them before the tribulation), separatist, and politically conservative. There are no firm figures on how many evangelical Christians consider themselves fundamentalists; among Baptists perhaps 5 million would identify with the fundamentalist label (Wardin 1980:27,33; Ammerman 1986:487). A recent poll (Kantzer 1980) estimated 29 million adult Americans identified themselves as charismatics or pentacostals. Many of them would agree with fundamentalists on most doctrinal and political questions, but they part company over the doctrine of charismas (the belief that the Holy Spirit manifests himself in the body of the believer through tongues, prophecy, and healing), which fundamentalists reject. A third major faction of born-again Christians, who are called neo-evangelicals, is more moderate or liberal politically, doctrinally, and socially than are fundamentalists. Finally, those who would simply describe themselves as evangelicals may be as doctrinally strict as fundamentalists but are more moderate in other respects. If Jerry Falwell is the emblematic fundamentalist preacher today; Jimmy Swaggert and Pat Robertson stand for the charismatics, at least the conservative ones; Jim Wallis for the neo-evangelicals; and Billy Graham for the evangelicals.

Jerry Falwell and most of the pastors allied with him are fundamental Baptists; they (but not all fundamental Baptists) are both evangelical (yet still in some respects Calvinist) and independent (nondenominational). They belong to the Baptist Bible Fellowship, a national network of preachers whose church members number about 1.5 million (Mead and Hill 1985:44). The Moral Majority, insofar as it is a grass roots organization, rides piggyback on the BBF (Liebman 1983) but draws support from the wider range of fundamentalists and politically conservative charismatics and evangelicals.

${ }^{2} \mathrm{I}$ am here summarizing Heirich (1977).

${ }^{3}$ Whitehead (1987) has an excellent, critical review of this literature in her study of conversion among Scientologists.

${ }^{4}$ Evangelical social scientists and theologians have studied the secular literature on conversion and generated their own. Elmer Towns, Dean of Jerry Falwell's Liberty Baptist Seminary and a nationally known researcher in the "science of church growth," told me that the highest rate of conversion occurred among prisoners, the second highest among the bankrupt; he also emphasized the importance of personal networks and of reaching people while they are "in transition" of some kind. The difference between Towns and secular social scientists is that Towns would never suggest any of these factors really causes conversion; the Holy Spirit convicts sinners and Christ saves them.

${ }^{5}$ This is how Bakhtin $(1981: 282)$ described ordinary dialogue from the speaker's point of view: "The speaker strives to get a reading on his own word, and on his own conceptual system that determines this word, within the alien conceptual system of the understanding receiver; he enters into dialogical relationships with certain aspects of this system. The speaker breaks through the alien conceptual horizon of the listener, constructs his own utterance on alien territory, against his, the listener's, apperceptive background."

${ }^{6}$ Compare Reverend Cantrell's language here with these words, which God spoke to Ezekiel regarding the nation of Israel (16:4-6, King James Version): "And as for thy nativity, in the day thou wast born thy navel was not cut, neither was thou washed in water to supple thee; thou wast not salted at all, nor swaddled at all. None eye pitied thee, to do any of these unto thee, to have compassion upon thee, but thou wast cast out in the open field, to the loathing of thy person, in the day that thou wast born. And when passed by thee, and saw thee polluted in thine own blood, 1 said unto thee when thou wast in thy own blood, Live; yea, I said unto thee, when thou wast in thy blood, Live."

'In fact, the listener can never really make the speaker's speech his own. Here is how Bakhtin (1981:293-294) described dialogue from the listener's point of view: "As a living, socio-ideological concrete thing, as heteroglot opinion, language, for the individual consciousness, lies on the borderline between oneself and the other. The word in language is half someone else's. It becomes 'one's own' only when the speaker [that is, the listener becoming a speaker] populates it with his own intention, his own accent, when he appropriates the word, adapting it to his own semantic and expressive intention. Prior to this moment of appropriation, the word does not exist in a neutral language . . ., but rather it exists in other people's mouths, in other people's contexts, serving other people's intentions: it is from there that one must take the word, and make it one's own. . . Expropriating it, forcing it to submit to one's own intentions and accents, is a difficult and complicated process."

${ }^{8 \prime \prime}$ It seems to me that to explain what is involved in [witchcraft] situations simply by talking of the effect of suggestion is not sufficient, for this is to do no more than to give a name to the very thing which is doubtful. ... So the touchstone of witchcraft is not so much the simple realization of a prediction or malediction, as the fact that it is taken up by the bewitched, who becomes the unwilling agent of fate" (FavretSaada 1980:113-114).

'Perhaps, as William James concluded about the divine, the only certain evidence of the reality that preoccupies ethnographers, of shared unconscious knowledge, is experiential. Faye Ginsburg (personal 
communication) put it this way: "Anthropologists approach self-alteration as a mode of knowing. Our epistemology requires that we alter ourselves in order to know." And Barbara Myerhoff, in her last film, In Her Own Time, said

This is what anthropologists are taught to do. You study what is happening to others by understanding what is going on in you, and you yourself become the data-gathering instrument. You come from a culture, and you step into a new culture, and how you respond to the new one tells you about them, and it tells you about the one you came from.

references cited

Alter, Robert

1981 The Art of Biblical Narrative. New York: Basic Books.

Ammerman, Nancy

1986 The New South and the New Baptists. The Christian Century, 14 May:486-488.

Bakhtin, Mikhail

1981 Discourse in the Novel. In The Dialogic Imagination: Four Essays by M. M. Bakhtin. Michael Holquist, ed. pp. 259-422. Austin: University of Texas Press.

Bauman, Richard

1977 Verbal Art as Performance. In Verbal Art as Performance. Richard Bauman, ed. pp. 3-58. Prospect Heights, IL: Waveland Press.

Borker, Ruth

n.d. The Presentation of the Gospel In Everyday Life. Unpublished manuscript.

Favret-Saada, Jeanne

1980 Deadly Words: Witchcraft in the Bocage. Cambridge: Cambridge University Press.

Gallup, George

1982 The Gallup Report: Religion in America. Princeton: Princeton Religion Research Center.

Graham, Billy

1983 Approaching Hoofbeats: The Four Horsemen of the Apocalypse. Waco, TX: Word Books.

Heirich, Max

1977 A Change of Heart: A Test of Some Widely Held Theories about Religious Conversion. American Journal of Sociology 83(3):653-680.

Hill, Samuel S.

1985 The South and the North in American Religion. Athens: University of Georgia Press.

James, William

1906 Varieties of Religious Experience. New York: Collier Books.

Jules-Rosette, Benneta

1976 The Conversion Experience: The Apostles of John Maranke. Journal of Religion in Africa $7(2): 132-164$.

Kantzer, Kenneth

1980 The Charismatics Among Us. Christianity Today 24 (22 February):25-29.

Liebman, Robert C.

1983 Mobilizing the Moral Majority. In The New Christian Right: Mobilization and Legitimation. Robert C. Liebman and Robert Wuthnow, eds. pp. 49-73. Hawthorne, NY: Aldine.

Mead, Frank S., and Samuel S. Hill

1985 Handbook of Denominations in the United States. Nashville: Abington Press.

Myerhoff, Barbara, and Lynn Littman

1986 In Her Own Time. Film.

Wardin, Albert W., Jr.

1980 Baptist Atlas. Nashville: Boardman Press.

Whitehead, Harriet

1987 Renunciation and Reformulation: A Study of Conversion in An American Sect. Ithaca: Cornell University Press.

submitted 1 May 1986

accepted 26 September 1986 